\title{
NECROTIZING FASCIITIS IN A NEWBORN INFANT: A CASE REPORT
}

\author{
Vera Lúcia Jornada Krebs, Karen Mayumi Koga, Edna Maria de Albuquerque
}

Diniz, Maria Esther Jurfest Ceccon and Flávio Adolfo Costa Vaz

RHCFAP/3037

KREBS VLJ et al. - Necrotizing fasciitis in a newborn infant: a case report. Rev. Hosp. Clín. Fac. Med. S. Paulo 56(2):59-62, 2001.

We report the case of a one-day-old newborn infant, female, birth weight $1900 \mathrm{~g}$, gestational age 36 weeks presenting with necrotizing fasciitis caused by E. coli and Morganella morganii. The newborn was allowed to fall into the toilet bowl during a domestic delivery. The initial lesion was observed at 24 hours of life on the left leg at the site of the venipuncture for the administration of hypertonic glucose solution. Despite early treatment, a rapid progression occurred resulting in a fatal outcome. We call attention to the risk presented by this serious complication in newborns with a contaminated delivery, and highlight the site of the lesion and causal agents.

\section{DESCRIPTORS: Necrotizing fasciitis. Bacterial infections. Neonate. Neonatal sepsis. Newborn.}

Necrotizing fasciitis occurs predominantly in adult patients. The initiating site is usually a local trauma or a surgical wound. In children, the disease is not common; however, frequently the clinical course is fatal ${ }^{1}$. The mortality rate among pediatric patients ranges from $10 \%$ to $60 \%{ }^{2}$. During the neonatal period, the occurrence of necrotizing fasciitis is rare and is generally associated with other infections, such as omphalitis and mammary infection ${ }^{3}$. Mortality is high, reaching over $70 \%$, even with precocious diagnosis and treatment ${ }^{4}$. These aspects of the disease's behavior demonstrate the importance of bearing in mind the predisposing factors and rigorous vigilance needed to treat the at-risk newborn. This case report describes our experience with a newborn with necrotiz- ing fasciitis that followed a massive contamination during the delivery.

\section{CASE REPORT}

The patient was a one-day-old girl, with a birth weight of $1900 \mathrm{~g}$ and a gestational age 36 weeks. The mother was 29 years old, and this was her second gestation without prenatal care. The birth took place at home, and the newborn was allowed to fall into the toilet bowl during delivery; the umbilical cord was severed with domestic scissors. Shortly after birth, the newborn was taken to the hospital where

From the Department of Pediatrics, Hospital das Clínicas, Faculty of Medicine, University of São Paulo. she received her first medical care and intravenous penicillin and amikacin therapy. At 90 minutes of life, she presented with hypoglycemia, necessitating intravenous infusion of $10 \%$ glucose. At 24 hours of life, hyperemia and edema of the left leg were observed at the site of the venipuncture and infiltration of intravenous solution. The clinical course was marked by a rapid deterioration of the lesion's appearance and extension. The infant was transferred to the Neonatal Intensive Care Unit (NICU) of the Children's Institute because of her worsening clinical course. On admission, she was in a poor general state, groaning, with decreased peripheral perfusion, an axillary temperature of $36^{\circ} \mathrm{C}$, tachycardia (160 beats/min), tachypnea (88 breaths/min), abdominal distention, her 
liver was $2.0 \mathrm{~cm}$ from the right costal arch, and her spleen was $1.0 \mathrm{~cm}$ from the left costal arch. Throughout the anterior fascia of the left leg, hard edema with a violet skin color and blistered lesions measuring $2.0 \mathrm{~cm}$ in diameter containing liquid with a fetid odor and bloody regions (Fig. 1) were observed. Results of the laboratory examinations were: $\mathrm{Hb}=17.2 \mathrm{~g} / \mathrm{dL} ; \mathrm{Ht}=46 \%$; Leukocytes $=2700 \mathrm{~mm}^{3}$; Platelets $=8000 /$ $\mathrm{mm}^{3} ; \mathrm{TP}=29.0 \mathrm{sec} ;$ TTPA=73.1 sec; Hemoculture: Morganella morganii and Escherichia coli; Cutaneous blister secretion: Escherichia coli. An escharotomy was performed, followed by total amputation of the left leg, 27 hours after hospitalization. The newborn was mechanically ventilated and administered fresh plasma, vasoactive drugs, ceftazidime, and amikacin. The course worsened rapidly resulting in pulmonary bleeding and bleeding at the puncture sites, persistent bradycardia, and death 48 hours after hospitalization.

\section{DISCUSSION}

Necrotizing fasciitis is characterized by a bacterial infection of the skin, subcutaneous fat, and superficial and deep fascia, with rapid dissemination and signs of systemic toxicity. Marked tissular edema occurs, which spreads rapidly into the fascial planes, causing vascular thrombosis, with necrosis of the subcutaneous cellular tissue and skin. The muscular layer can also be affected. The initial appearance of the lesion varies from a discrete rash to the appearance of erythema, edema, hardening, and cellulite. The skin develops a violet coloration with blistering and areas of necrosis ${ }^{5}$. Crepitation is not common, but fever, tachycardia, and leukocytosis with a deviation to the left are frequent. Thrombocytopenia, as observed in this patient, occurs in approximately half of all cases 6 .

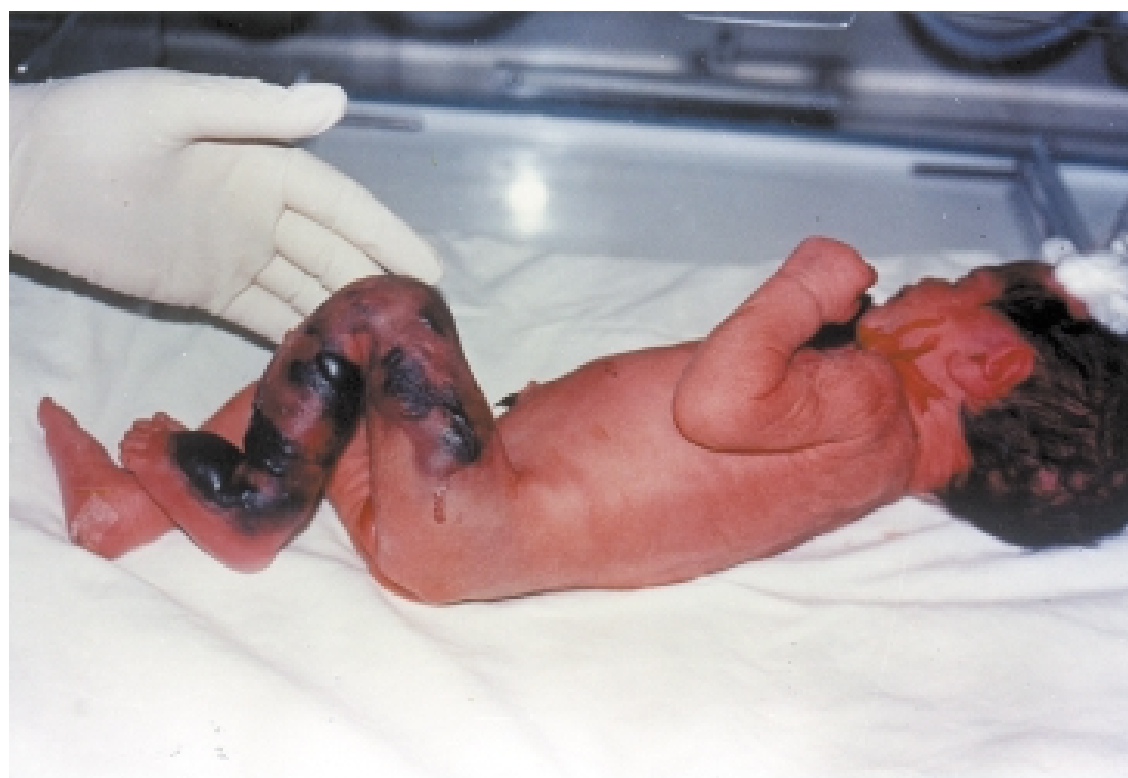

Figure 1 - Necrotizing fasciitis covering the anterior face of the left leg: generalized edema, violetcolored skin, blisters, and bloody regions.

The disease occurs predominantly in adult patients and is rare in children, especially during the neonatal period. In a recent review of the literature, covering 28 years (1972-1999), Hsieh et al. ${ }^{6}$ found only 66 cases, with the exception of 3 cases reported by them. Umbilical infection has been reported in some $70 \%$ of the cases, and as such is the most frequent entry site. Other associated conditions are mastitis, balanitis, fetal monitoring with electrodes in the scalp, necrotizing enterocolitis, immunodeficiency, impetigo with blistering, and maternal mastitis. In our patient, the initial lesion was observed in the left leg, at the venipuncture site for the administration of hypertonic glucose solution. Lesions at this site are not usual, with only 2 such cases reported in the literature ${ }^{6}$. Rupture of the tegumentary barrier following venipuncture and severe contamination during the delivery appear to be the predominant factors in the initiation of the disease. Furthermore, the newborn had serious leukopenia, low birth weight, and prematurity, which may have contributed to the unfavorable outcome. Contrary to our experience, the majority of authors have observed the disease in term newborns ${ }^{4,7-9}$. In the literature review by Hsieh et al., only 3 cases were preterm 6 .

A fulminating course is frequent in neonates with necrotizing fasciitis, even with an early diagnosis and therapeutic treatment. On hospitalization in the NICU at only 24 hours of life, our patient already had signs of cellulite in the left leg, which rapidly compromised all the tissular planes. Samuel et al. ${ }^{9}$ reported 14 cases, with only 2 survivors, and emphasized the fact that the patients initially appear to be responding, but rapid deterioration in the general state occurs, and death follows within 72 hours. The most frequent causal agent of neonatal necrotizing fasciitis is Staphylococcus aureus, observed in two-thirds of all cases and is related to the presence of omphalitis and mastitis ${ }^{3,8}$. Various authors $2,4,5,7$ have observed the association of bac- 
teria. In our patient, the presence of $E$. coli and Morganella morganii in the hemoculture and cutaneous blister secretion are consistent with the type of contamination during the delivery.

We call attention to the occurrence of necrotizing fasciitis as an infectious complication following deliveries with- out medical assistance and highlight the site of the lesion, causal agents, and fulminating clinical course.
KREBS VLJ e col. - Fasciíte necrosante em neonato: relato de caso. Rev. Hosp. Clín. Fac. Med. S. Paulo 56(2):59-62, 2001.

Os autores relatam o caso de um recém-nascido com um dia de vida, sexo feminino, com peso de nascimento de $1900 \mathrm{~g}$ e idade gestacional de 36 semanas que apresentou fasciíte necrosante causada por $E$. coli e Morganella morganii. O parto foi domiciliar, com queda acidental no vaso sanitário durante o nascimento. A lesão inicial foi observada com 24 horas de vida, na perna esquerda em local de venopunção para a administração de solução de glicose hipertônica. Apesar do tratamento precoce, houve progressão rápida, com evolução fatal. Os au- tores chamam a atenção para o risco desta complicação grave em recémnascido de parto contaminado, destacando o local da lesão e os agentes etiológicos.

\section{DESCRITORES: Fasciíte} necrosante. Infecções bacterianas. Neonato. Sepse neonatal. Recémnascido.

\section{REFERENCES}

1. WILSON HD \& HALTALIN KC - Acute necrotizing fasciitis in childhood. Am J Dis Child 1999; 125:591-5.

2. MURPHY JJ, GRANGER R, BLAIR GK et al.- Necrotizing fasciitis in childhood. J Pediatr Surg 1995; 30:1131-4.

3.BODEMER C, PANBANS A, CHRETIEN-MARQUET B et al. Staphylococcal necrotizing fasciitis in the mammary region in childhood. A report of five cases. J Pediatr 1997; 131:466.
3. SAWIN RS, SCHALLER RT, TAPPER D et al. - Early recognition of neonatal abdominal wall necrotizing fasciitis. Am J Surg 1994; 167:481-4.

5. GIULIANO A, LEWIS Jr F, HADLEY K et al. - Bacteriology of necrotizing fasciitis. Am J Surg 1977; 134:52-6.

6. HSIEH WS, YANG PH, CHAO HC et al. - Neonatal Necrotizing Fasciítis: A report of three cases and review of the literature (abstract e 53). Pediatrics 1999; 103(4):810. 
7. BLISS Jr DP, HEALEY PJ \& WAULDBAUSEN JHT - Necrotizing fasciitis after Plastibell circumcision. J Pediatr 1997; 131:45962.

8. CHEN JW, BROADBENT RS \& THOMSON IA - Staphylococcal neonatal necrotizing fasciitis: survival without radical debridement. N Z Med J 1998; 111:251-3.
9. SAMUEL M, FREEMAN NV, VAISHNAV A et al. - Necrotizing Fasciitis: a serious complication of omphalitis in neonates. J Pediatr Surg 1994; 29:1414-6.

Received for publication on February 14, 2001. 